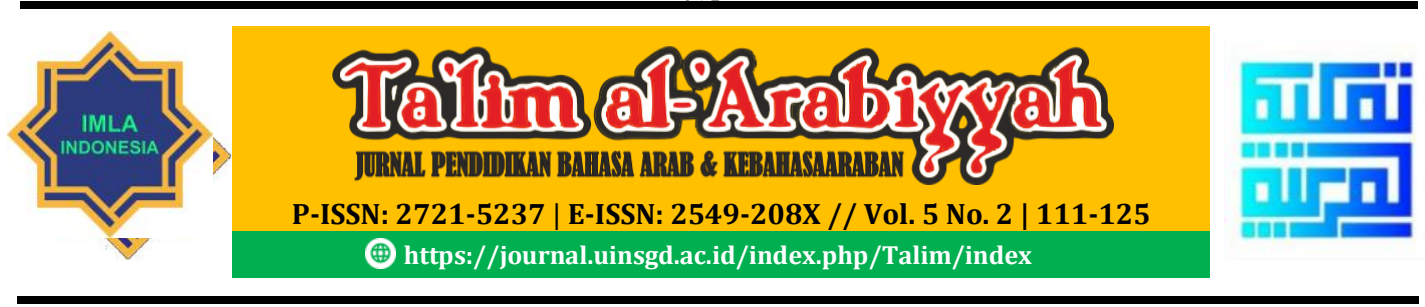

\title{
The Effectiveness of The Iqra' Wheel Game to Enhance Students' Arabic Reading Skills at State Islamic Senior High School 1 Malang
}

\author{
Rizki Safitri Yanwari ${ }^{1}$, Anisatu Thoyyibah ${ }^{2}$, M. Ainur Raziqi ${ }^{3}$ \\ ${ }_{1,2,3}$ Universitas Muhammadiyah Malang \\ Corresponding E-mail: anisatu thoyyibab@,umm.ac.id
}

\section{ABSTRACT}

Learning media appears to be a pivotal need for learning programs used to reach learning objectives. This study aims to determine the application and effectiveness of the Iqra' wheel game to enhance students' Arabic reading skills. This study uses a quantitative approach with the type of experiment. The subjects used are language students of tenth grade and $2^{\text {nd }}$ MIPA students of tenth grade with a sample of 60 students. Methods used observation, interviews, questionnaires, tests, and documentation. Data analysis techniques used in research are validity test, reliability test, sample t-test, and effectiveness test. The research findings showed a significant difference between the pre-test and post-test scores. The pre-test score is more minor than the post-test score of $84.41<90.58$. The percentage of $\mathrm{N}$-Gain shows $38.23 \%$, with a quite effective category. It can be concluded that the Iqra wheel game is "quite effective" in improving Arabic reading skills.

Keywords: Arabic Reading Skill, Game Media, Iqra' Wheel

\section{ABSTRAK}

Media pembelajaran merupakan kebutuhan program belajar yang digunakan untuk mencapai tujuan pembelajaran. Penelitian ini bertujuan untuk mengetahui penerapan dan efektivitas permainan roda iqra'. Penelitian ini menggunakan pendekatan kuantitatif dengan jenis penelitian eksperimen. Subyek yang digunakan siswa kelas X-Bahasa dan X-MIPA 2 dengan jumlah sampel 60 siswa. Metode pengumpulan data menggunakan observasi, wawancara, angket, tes, dan dokumentasi. Teknik analisis data yang digunakan dalam penelitian ini adalah uji validitas, uji reliabilitas, uji t sampel berhubungan dan uji efektivitas. Hasil penelitian menunjukkan bahwa ada perbedaan yang signifikan antara nilai pretest dan posttest. Nilai pretest lebih kecil dibandingkan nilai posttest 84,41<90,58. Persentase N-Gain menunjukkan angka 38,23\% dengan kategori "cukup efektif'. Dapat disimpulkan bahwa permainan roda iqra "cukup efektif" digunakan dalam meningkatkan keterampilan membaca bahasa Arab.

Kata Kunci: Keterampilan Membaca Bahasa Arab, Media Permainan, Roda Iqra' 


\section{INTRODUCTION}

Arabic is considered one of the worldwide recognized foreign languages since the Middle Ages. Arabic has been acknowledged as an international language as it is reportedly considered the most significant language globally. This statement is also supported by the fact that Arabic has been the fifth official language of the United Nations (UN) since 1973 (Ramadhani, 2018). Nowadays, Arabic has appeared to become one of the most studied foreign languages in both formal education and nonformal education, starting from the primary school (MI/SD) level, Junior High School (MTS/SMP) level, Senior High School (MA/SMA) level, up to university level (Lutfitayun, 2015). This noticeable condition is provable by the existence of regulation of the Minister of Religion of the Republic of Indonesia number 912 of 2013: 2), which sounds: "to set up the 2013 Madrasah curriculum for Islamic religious education and Arabic subjects". In the meantime, Arabic once appeared to be one of the keys to successful education during the Islamic civilization; thus, it is an honor for students worldwide to learn Arabic and continue their education in Arabic (Zedan et al., 2013).

The original and significant purpose of learning Arabic is to explore and enhance learners' proficiency while using language both orally and non-orally. The ability to use language is called language skill. The scopes included in Arabic language skills comprise listening, speaking, reading, and writing. As stated by (Muradi 2013). the purpose of learning Arabic is to understand Arabic correctly, to listen to living conditions generally and specifically, to speak Arabic and to utilize it as a medium of direct and indirect communication, and to read Arabic easily thus they can discover and encounter the meanings of Arabic, and to write something by Arabic as a form of expression regarding functional and other conditions.

Schools prepare Arabic language learning to achieve essential language competencies, including the language skills taught such as listening (مهارة الاستماع)( مهارة), speaking (مهارة الكلام), reading (مهارة القراءة), and writing (مهارة الكتابة) (decision of the director-general of Islamic education in the year 2013). If students master all ranges of language skills orally and non-orally, it can be illustrated that Arabic learning is reportedly considered successful (Lutfitayun, 2015). Moreover, one of the skills commonly taught in schools/madrasas is reading. A person's reading ability continues to develop since he begins his formal education. Since the beginning of his formal education, he learned language skills, particularly reading (Sumantri et al., 2017).

Reading is a process of gaining information and knowledge. Reading is a process done and used by the reader to receive messages; a method used to communicate with oneself sometimes others who communicate the meaning contained or implied in written symbols (Irdawati; Yunidar; dan Darmawan, 2017). Reading skill seems to be indispensable in learning Arabic because illiterate students will face massive difficulties in learning. Students will obtain difficulty capturing and understanding the information in Arabic textbooks, supporting books, and others. Reading skills are considered a 
pivotal ability to learn new words in books and other resources (Verhoeven \& Perfetti, 2011).

There seem to be wide disparities between beginners and skilled ones, as skilled readers already provide further insight into cognitive processes while reading (Mancheva et al., 2015). In addition to using models, methods, and good reading techniques, learning to read will appear to be full of fun while using media. The researcher uses an iqra' wheel game media when learning reading skills. As written by education experts, they admit that game media in teaching and learning is crucial. With playing techniques, a person can tackle difficulties and even combat problems. Furthermore, by playing, a learner can gain enjoyment metal the learner can solve problems with a cheerful atmosphere without pressure (Lutfitayun, 2015).

Learning is one of the teachings and studying activities conducted optimally by a teacher to participate in learning activities well. In other words, learning is one of the efforts set up by educators in delivering conductive material to achieve goals (Hermawan, 2018). Hence, educators must have effective methods and approaches while learning. Given the importance of mastering the skills aspect in language learning, especially reading learning, the development of activity-based teaching materials is appropriately valid (Priyatni, 2014). The most crucial problem in learning Arabic is the whole question of the seriousness of students' learning and the seriousness of the teachers' teaching. This seriousness of learning and teaching cannot be preceded by an attitude of being forced to follow a curriculum structure to install creative freedom and acquire skill knowledge (Fahrurrozi, 2014). The learning process plays a pivotal role in activating learning and achieving optimal learning goals (Murda \& Purwanti, 2017)

Based on the results of observations and interviews conducted by researchers towards Arabic language teachers at State Islamic Senior High School of 1 Malang, Arabic reading skills still need improvement. Several students remain incapable of understanding written Arabic because not all students graduate from various Islamic Junior High Schools or so-called Madrasas. In addition, while teaching, the teacher only explains the material and gives assignments. Practical activities still require guidance as reading activities require intensive direction so that the objectives of learning reading skills are achieved optimally.

Based on these problems illustrated, the solutions offered by previous research comprise Arabic puzzle book media (Ibadi Rohman 2015), CESAR card media (liya Lutfiyatul 2015), rotating wheel media (hamzah 2019). The solution that will be applied by the researcher in tackling the problems of learning Arabic is to use the iqra' wheel game. The iqra' wheel game is an Arabic language learning medium in the form of a wheel or round and can be rotated, in which it has a question. The question comes from the reading text studied previously. The application of this media is used as a support so that students are more enthusiastic and happier in learning Arabic.

\section{METHOD}


This research uses quantitative research whose type is experimental research. The population used in this study were students of class X state Islamic Senior High School of 1 Malang. Moreover, the sample used is class X Language Major and X Mathematics and Natural Sciences Major 2 (MIPA-2) with a total range of 60 students.

Furthermore, the methods of collecting data used in this study encompass observations, interviews, questionnaires, tests, and documentation. While observations were conducted to describe the object to study, interviews were conducted to obtain information needed by the researcher. Meanwhile, the questionnaire in this study was used to determine the effectiveness of the iqra' wheel game and student responses to the iqra' wheel game. The test determines the difference in student learning outcomes before and after using the iqra' wheel game media. Documentation is carried out to obtain vital matters associated with the learning process and documents related to student learning outcomes.

The data analysis used is validity test, reliability test, related t-sample test, and effectiveness test. Validity aims to measure the level of accuracy of the size of an instrument against the concept studied. A reliability test is conducted to determine the consistency of a reliable tool to measure a measurable object. The t-test sample test aims to discover whether there is a disparity between the pre-test and post-test results. The effectiveness test is used to determine the level of effectiveness of the media used.

\section{RESULT AND DISCUSSION}

In the meantime, this research instrument comprises interviews to find out the information needed by the researcher as interviews were conducted before the study. Moreover, the researcher conducted interviews with Mrs. Hidayatus as an Arabic language teacher at State Islamic Senior High School of 1 Malang. Based on the interviews conducted by the researcher with tutors, it can be concluded that students' reading skills at State Islamic Senior High School of 1 Malang Remain are unsatisfactory because not all students come from Islamic Junior High School backgrounds, and not all students all students have also studied Arabic. Meanwhile, it can also be said that the use of learning methods is still monotonous, and students' interest in learning Arabic remains low.

Before conducting the research, the researcher made the iqra' wheel game media for this study. The application of this iqra' wheel game media is carried out by dividing students into several small groups, and each group has a group leader. The teacher appoints which group answers first. Then, the designated group answers the questions on the iqra' wheel. If the group members cannot answer the question, the question will be assigned to another group. The group answering the question given will get a score or points. Finally, the group with the biggest score in total is the winner. 
Ta'Cim al-'Arabiyyah : Jurnal Pendidikan Bahasa Arab dan Kebahasaaraban, 5 (2), 2021

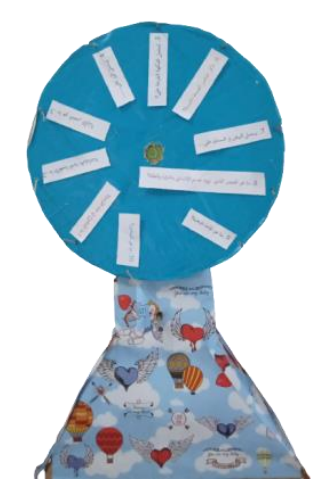

Figure 1 Iqra' Wheel

Figure 1 can be understood that each color above contains a question related to the theme of the reading that has been studied. Each question has points, so each student must be competent to get points.

The form of data processing from the questionnaire results is shown in the form of a bar chart as follows:

\section{Student Interest in the Iqra' Wheel Game Iqra'}

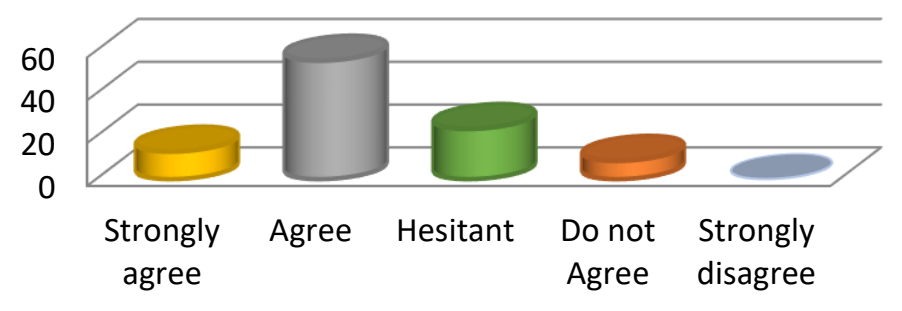

Figure 2 Student Interest in the Iqra' Wheel Game Iqra'

Figure 2 shows students' interest in the wheel game. Students who strongly agree with the interest in the iqra' wheel game are $12.8 \%$, while students who feel agree are $55.3 \%$, students who feel doubtful are $23.4 \%$ students who feel disagree are $8.5 \%$, and students who strongly disagree as much as $0 \%$. 


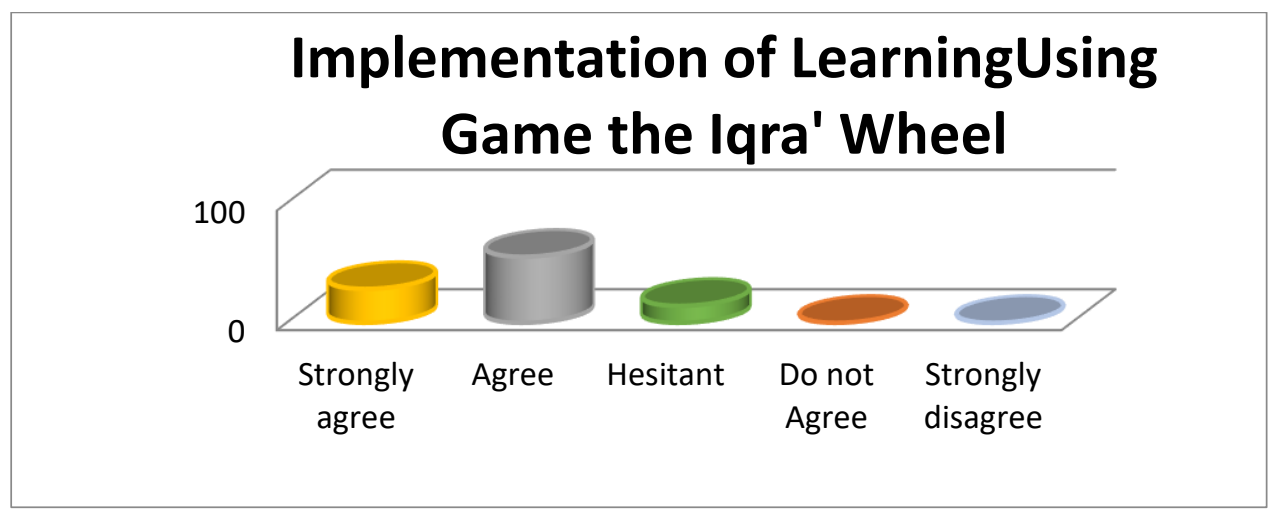

Figure 3 Implementation of Learning Using the Iqra' Wheel Game

Figure 3 shows the implementation of learning using the iqra' wheel game with the number of responses from students who chose strongly agree as much as $28.4 \%$, students who chose to agree as much as $53.2 \%$, while students who chose to hesitate as much as $14.2 \%$, students who chose to disagree as much as $0 \%$, and students who chose strongly disagree as much as $0 \%$.

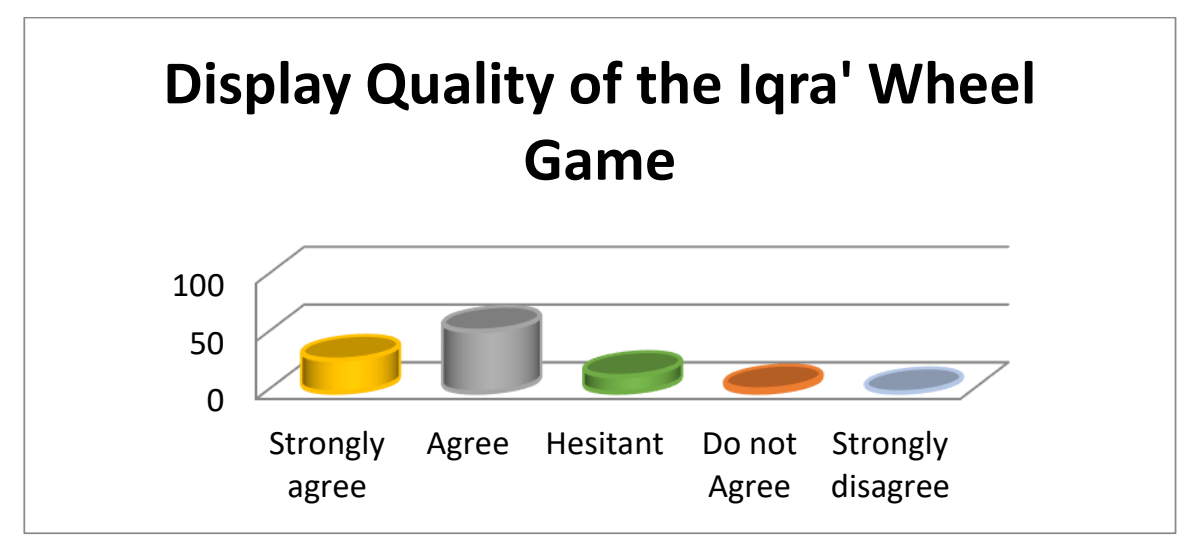

Figure 4 Display Quality of the Iqra' Wheel Game

Figure 4 shows the quality of the iqra' wheel game. Students seem to like the appearance of the iqra' wheel game with the number of responses from students who choose strongly agree as much as $28.2 \%$, students who choose to agree as much as $53.3 \%$, while students who choose to hesitate as much as $14.1 \%$, students who choose to disagree as much as $2.5 \%$, and students who choose strongly disagree as much as $0 \%$. 


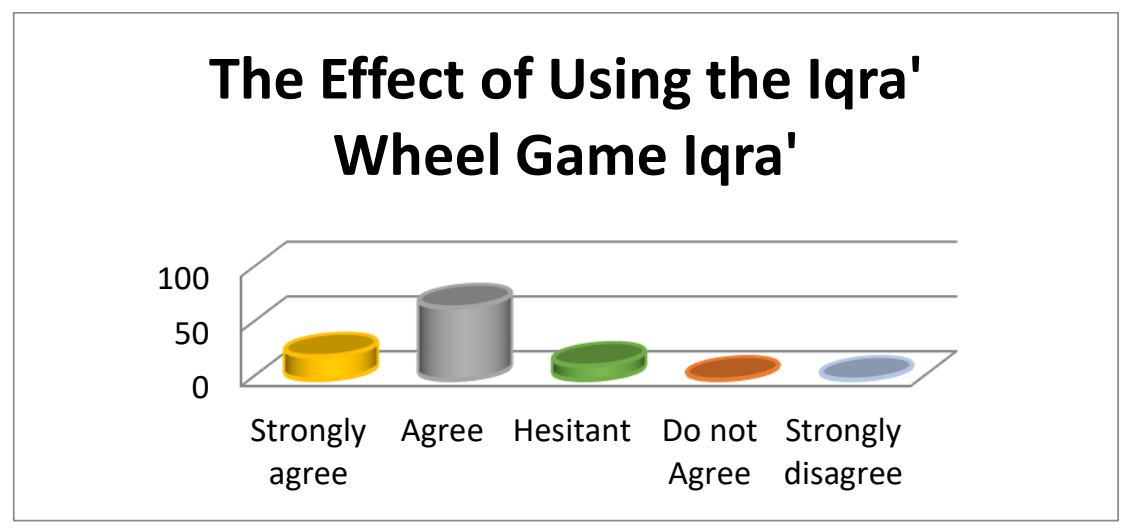

Figure 5 The Effect of Using the Iqra' Wheel Game Iqra'

Figure 5 shows the effect of using the wheel game with the number of responses from students who chose strongly agree as much as $21.3 \%$, students who chose to agree as much as $66 \%$, while students who chose hesitantly as many as $12,8 \%$, students who chose to disagree as much as $0 \%$, and students who chose to disagree as much as $0 \%$ strongly.

Based on the analysis of questionnaire data given to students of class X Language and Mathematics and Natural Sciences 2, it can be concluded that students are more interested when learning Arabic using the iqra' wheel game. Students feel more enthusiastic and active when using the iqra' wheel game. Based on the quality of the game, the iqra' wheel is quite effective for use in learning Arabic. Iqra' wheel game is very influential in learning Arabic.

In addition to questionnaires, researchers used tests to obtain data on the results of learning evaluations. Researchers used pre-test and post-test questions to obtain results in the evaluation of learning, in which the test was taken from the material being studied.

The following is the data analysis of the pre-test and post-test scores:

Table 1 Pretest and Posttest Value Data Analysis

\begin{tabular}{ccccccc}
\hline Soal & N & Mean & Median & $\begin{array}{c}\text { Nilai } \\
\text { Minimum }\end{array}$ & $\begin{array}{c}\text { Nilai } \\
\text { Maksimum }\end{array}$ & $\begin{array}{c}\text { Jarak } \\
\text { Nilai }\end{array}$ \\
\hline Pretest & 60 & 84,41 & 85 & 70 & 90 & 20 \\
Posttest & 60 & 90,58 & 90 & 80 & 95 & 15 \\
\hline
\end{tabular}

Table 1 explains that the average value of student learning outcomes after applying the iqra' wheel game media to improve Arabic reading skills is 90.58 , which 
Ta'lim al-'Arabiyyah : Jurnal Pendidikan Bahasa Arab dan Kebahasaaraban, 5 (2), 2021

can be concluded that the student's learning outcomes are classified as a perfect category in learning Arabic. A validity test is a measurement that shows the level of accuracy of the size of an instrument against the concept under study.

Table 2 Results of Angket Validity Test

\begin{tabular}{|c|c|c|c|c|c|c|}
\hline Indikator & Item & $\begin{array}{c}\text { R } \\
\text { Hitung }\end{array}$ & $\begin{array}{c}\text { R } \\
\text { Tabel }\end{array}$ & Skor Akhir & $\begin{array}{l}\text { Nilai } \\
\text { Sig }\end{array}$ & Keterangan \\
\hline \multirow{5}{*}{$\begin{array}{c}\text { Student Interest } \\
\text { in the Iqra' } \\
\text { Wheel Game } \\
\text { Iqra' }\end{array}$} & 1 & 0,618 & 0,250 & $0,618>0,2500$ & 0,000 & Valid \\
\hline & 2 & 0,371 & 0,250 & $0,371>0,2500$ & 0,004 & Valid \\
\hline & 3 & 0,467 & 0,250 & $0,467>0,2500$ & 0,000 & Valid \\
\hline & 4 & 0,458 & 0,250 & $0,458>0,2500$ & 0,000 & Valid \\
\hline & 5 & 0,476 & 0,250 & $0,476>0,2500$ & 0,000 & Valid \\
\hline \multirow{5}{*}{$\begin{array}{c}\text { Implementation } \\
\text { of Learning } \\
\text { UsingGame } \\
\text { the Iqra' Wheel. }\end{array}$} & 6 & 0,316 & 0,250 & $0,316>0,2500$ & 0,014 & Valid \\
\hline & 7 & 0,537 & 0,250 & $0,537>0,2500$ & 0,000 & Valid \\
\hline & 8 & 0,619 & 0,250 & $0,619>0,2500$ & 0,000 & Valid \\
\hline & 9 & 0,530 & 0,250 & $0,530>0,2500$ & 0,000 & Valid \\
\hline & 10 & 0,599 & 0,250 & $0,599>0,2500$ & 0,000 & Valid \\
\hline \multirow{5}{*}{$\begin{array}{c}\text { Display Quality } \\
\text { of the Iqra' } \\
\text { Wheel Game }\end{array}$} & 11 & 0,498 & 0,250 & $0,498>0,2500$ & 0,000 & Valid \\
\hline & 12 & 0,350 & 0,250 & $0,350>0,2500$ & 0,006 & Valid \\
\hline & 13 & 0,274 & 0,250 & $0,274>0,2500$ & 0,034 & Valid \\
\hline & 14 & 0,303 & 0,250 & $0,303>0,2500$ & 0,019 & Valid \\
\hline & 15 & 0,456 & 0,250 & $0,456>0,2500$ & 0,000 & Valid \\
\hline \multirow{5}{*}{$\begin{array}{c}\text { The Effect of } \\
\text { Using the Iqra' } \\
\text { Wheel Game } \\
\text { Iqra' }\end{array}$} & 16 & 0,460 & 0,250 & $0,460>0,2500$ & 0,000 & Valid \\
\hline & 17 & 0,397 & 0,250 & $0,397>0,2500$ & 0,021 & Valid \\
\hline & 18 & 0,279 & 0,250 & $0,279>0,2500$ & 0,031 & Valid \\
\hline & 19 & 0,467 & 0,250 & $0,467>0,2500$ & 0,000 & Valid \\
\hline & 20 & 0,265 & 0,250 & $2,65>0,2500$ & 0,250 & Valid \\
\hline
\end{tabular}


Ta'lim al-'Arabiyyah : Jurnal Pendidikan Bahasa Arab dan Kebahasaaraban, 5 (2), 2021

Based on table 2 , the results of the questionnaire validity test show that all items have significant results with $\mathrm{r}$ count $>\mathrm{r}$ table $(0.250) \mathrm{N}=60$, with a significance value less than 0.05 . With this, it can be concluded that all item items can be proven valid to be used as a measuring tool in a study.

Table 3 Results of Pretest Validity Test

\begin{tabular}{cccccc}
\hline Item & R hitung & R tabel & Skor Akhir & Nilai Sig & Keterangan \\
\hline 1 & 0,301 & 0,250 & $0,301>0,250$ & 0,020 & Valid \\
2 & 0,382 & 0,250 & $0,382>0,250$ & 0,003 & Valid \\
3 & 0,320 & 0,250 & $0,320>0,250$ & 0,013 & Valid \\
4 & 0,516 & 0,250 & $0,516>0,250$ & 0,000 & Valid \\
5 & 0,290 & 0,250 & $0,290>0,250$ & 0,025 & Valid \\
\hline
\end{tabular}

Based on table 3 , the results of the validity test of the pre-test items showed that all items had significant results with $r$ count $>\mathrm{r}$ table $(0.250) \mathrm{N}=60$, with a significance value less than 0.05 . With this, it can be concluded that all item items can be proven valid to be used as a measuring tool in a study.

A reliability test is conducted to determine the consistency of a reliable tool to measure an object that can be measured.

Table 4 Results of Reliability Test Indicator 1

\begin{tabular}{cccc} 
Variable & $\begin{array}{c}\text { Cronbach's } \\
\text { alpha }\end{array}$ & $\begin{array}{c}\text { Standard } \\
\text { reliability }\end{array}$ & Keterangan \\
\hline $\begin{array}{c}\text { Student Interest in the Iqra' } \\
\text { Wheel Game Iqra' }\end{array}$ & 0,507 & 0,60 & Reliable \\
$\begin{array}{c}\text { Implementation of Learning } \\
\text { UsingGame }\end{array}$ & 0,820 & 0,60 & Reliabel \\
the Iqra' Wheel. & 0,483 & 0,60 & Reliabel \\
$\begin{array}{c}\text { Display Quality of the Iqra' } \\
\text { Wheel Game }\end{array}$ & 0,290 & 0,60 & Reliabel \\
$\begin{array}{c}\text { The Effect of Using the } \\
\text { Iqra' Wheel Game Iqra' }\end{array}$ & & & \\
\hline
\end{tabular}


Ta'lim al-'Arabiyyah : Jurnal Pendidikan Bahasa Arab dan Kebahasaaraban, 5 (2), 2021

Based on table 4, it can be seen that the questionnaire indicators have Cronbach's alpha greater than $0.60(>0.60)$. So the basis for taking the reliability test above can be concluded that all items in the questionnaire are reliable or consistent.

Table 5 Pretest Reliability Test Results

\begin{tabular}{cccc}
\hline Variable & Cronbach's alpha & Standart reliability & Keterangan \\
\hline Nilai pretest & 0,436 & 0,60 & Reliabel \\
\hline
\end{tabular}

Based on table 5, it can be seen that five pre-test items are using Cronbach's alpha $0.436>0.60$. So the basis for taking the reliability test above can be concluded that all items in the test are reliable or consistent.

Table 6 Posttest Reliability Test Results

\begin{tabular}{cccc}
\hline Variable & Cronbach's alpha & Standart reliability & Keterangan \\
\hline Nilai posttest & 0,781 & 0,764 & Reliabel \\
\hline
\end{tabular}

Based on table 6 , it can be seen that ten post-test items are using Cronbach's alpha $0.436>0.60$. So the basis for taking the reliability test above can be concluded that all items in the test are reliable or consistent.

Hypothesis testing was conducted to determine whether there was a difference between the pre-test and post-test results after using the iqra' wheel game media.

Tabel 7 Paired Samples Statistics

\begin{tabular}{c|ccccc}
\hline \multicolumn{2}{c}{} & Mean & $\mathrm{N}$ & Std. Deviation & Std. Error Mean \\
\hline P & PRETEST & 84.4167 & 60 & 5.29564 & .68366 \\
ai & POSTTEST & 90.5833 & 60 & 4.42371 & .57110 \\
r & POT & & & & \\
\hline
\end{tabular}

Based on table 7 , we can see a summary of the descriptive statistical results of the two samples studied, namely the pre-test and post-test scores, if the pre-test obtained an average learning outcome or mean of 84.4167. As for the post-test value, the mean is 90.5833 . The number of respondents used as a sample in this study was 64 students because the average value of learning outcomes in the pre-test is $84.4167<90.5833$, 
Ta'Cim al-'Arabiyyah : Jurnal Pendidikan Bahasa Arab dan Kebahasaaraban, 5 (2), 2021

descriptively, there is a difference in the average learning outcomes between the pre-test and post-test.

Tabel 8 Paired Samples Correlations

\begin{tabular}{ccccc}
\hline & & $\mathrm{N}$ & Correlation & Sig. \\
\hline $\begin{array}{c}\text { Pair } \\
1\end{array}$ & PRETEST POSTTEST & 60 & .648 & .000 \\
\hline
\end{tabular}

Table 8 shows the results of the correlation test between the two data. Because of the value of Sig $0.000<0.05$, it can be said that there is a relationship between the pretest and post-test variables.

Table 9 Paired Samples Test

\begin{tabular}{|c|c|c|c|c|c|c|c|c|c|}
\hline & & \multicolumn{5}{|c|}{ Paired Differences } & \multirow[b]{2}{*}{$\mathrm{t}$} & \multirow[b]{2}{*}{ Df } & \multirow[b]{2}{*}{$\begin{array}{l}\text { Sig. } \\
(2- \\
\text { tailed })\end{array}$} \\
\hline & & Mean & $\begin{array}{l}\text { Std. } \\
\text { Dev } \\
\text { iatio } \\
\mathrm{n}\end{array}$ & $\begin{array}{l}\text { Std. } \\
\text { Err } \\
\text { or } \\
\text { Me } \\
\text { an }\end{array}$ & \multicolumn{2}{|c|}{$\begin{array}{c}95 \% \text { Confidence } \\
\text { Interval of the } \\
\text { Difference }\end{array}$} & & & \\
\hline $\begin{array}{l}\mathrm{P} \\
\text { ai } \\
\mathrm{r} \\
1\end{array}$ & $\begin{array}{c}\text { PRE } \\
\text { TES- } \\
\text { POS } \\
\text { TTE } \\
\text { ST }\end{array}$ & $\begin{array}{c}- \\
6.166 \\
67\end{array}$ & $\begin{array}{l}4.15 \\
450\end{array}$ & $\begin{array}{l}.53 \\
634\end{array}$ & $\begin{array}{c}- \\
7.239 \\
89\end{array}$ & $\begin{array}{c}- \\
5.09344\end{array}$ & $\begin{array}{l}- \\
1 \\
1 . \\
4 \\
9 \\
8\end{array}$ & 59 & .001 \\
\hline
\end{tabular}

Based on table 9, it can be seen that the value of Sig (2-tailed) is $0.001<0.05$, which means $\mathrm{HA}$ is accepted and $\mathrm{H} 0$ is rejected, so it can be concluded that the average difference between learning outcomes before and after treatment to students, which means game media iqra' wheel can improve Arabic reading skills at MAN 1 Malang.

The effectiveness test was conducted to determine the level of effectiveness of the media used in the research process. The researcher uses the N-Gain formula to determine the iqra' wheel game media's effectiveness in improving reading skills. 


$$
\begin{gathered}
N-\text { Gain }=\frac{\text { Skor posttest-skor pretest }}{\text { Skor maksimum-skor pretest }} \\
\text { N-Gain }=\frac{\text { Skor posttest }- \text { skor pretest }}{\text { Skor maksimum }- \text { skor pretest }} \quad \text { X } 100
\end{gathered}
$$$$
5435-5065
$$$$
\text { × } 100
$$$$
100-5065
$$$$
\mathrm{N} \text {-gain }=38,23 \%
$$

\section{Analysis}

Learning media is a tool to carry messages or information with instructional purposes or teaching purposes (Baroroh \& Mardliyyah, 2019). Media types of learning materials are divided into three categories: printed material media (Mawad Mathbu'ab) such as books, pictures, maps, cards, and symbols. The media for viewing-hearing material does not move like a motionless film. The media for viewing and hearing moving materials such as films, cassettes, videos, and VCDs (Muna, 2014). Moreover, media selection is supposed to pay attention to several principles, such as the clarity of the intent and purpose of selecting media for entertainment, learning, and other purposes. The researcher conducted a study using the iqra' wheel game media based on this statement. The iqra' wheel game is an Arabic learning medium in the form of a circle that can be rotated and has questions. These questions come from reading texts that have been studied previously. Furthermore, the selection iqra' wheel media is carried out to improve students' creative thinking skills because the iqra' wheel media can be used to stimulate children to think creatively. In this discussion, the researcher focuses more on Arabic learning media, specifically reading skills.

The learning materials used in this study were taken from the K-13 Arabic language book entitled "Madrasah Aliyah Arabic Student Book Class X" published by the Directorate of KSKK Madrasas and the Directorate General of Islamic Education. The form of implementation that the researchers did was using the iqra' wheel game media in class X Language and Mathematics and Natural Sciences 2 MAN 1 Malang. To find out the results obtained by students in improving Arabic reading skills using the iqra' wheel game media, the researchers gave an evaluation in the form of questions packaged in the iqra' wheel. The calculation of the effectiveness test results were 
obtained using the $\mathrm{N}$-Gain formula of $38.23 \%$, which means that the iqra' wheel game media is effective in improving Arabic reading skills in class X Language and MIPA 2 MAN 1 Malang.

The outcomes of students' learning in reading skills using the iqra' wheel game media are illustrated by the average pre-test score of 84.41 and post-test of 90.58 . Based on the analysis of the paired-sample t-test as a measuring tool in the test, $0.001<0.05$. It depicts a significant difference in the average student learning outcomes between the pre-test and post-test. Based on the average and hypothesis testing, students' learning outcomes using the iqra' wheel game media are better than the previous students' learning outcomes. It can be concluded that the iqra' wheel game media is effective on student learning outcomes at State Islamic Senior High School of 1 Malang. The assessment findings reveal the progress that students have made in theoretical and practical aspects.

Moreover, it can also help teachers respond to each student's abilities (Al-Basheer et al., 2015). Education experts recognize the need to use games as an educational medium or as a teaching and learning technique. While playing, a gamer feels involved and called upon to tackle difficulties and combat problems. More importantly, the gamer will also gain pleasure so that solving problems runs in an atmosphere of joy without pressure. Game media can provide an exciting environment for problemsolving and meaning-making and create spaces for collaborative learning both inside and outside games (Whitton \& Maclure, 2017).

Game-based learning continues to gain traction as an influential tool for facilitating learning. It has probably been effective in motivating students to learn in a fun way and has been proven to increase knowledge and skill retention. Moreover, the game is also considered an effective educational strategy because students become more active in learning through gaming (Ignacio \& Chen, 2020). Games in education can increase students' motivation, excitement, pride in achievement, desire, competition, and challenges; thus, it can increase attention (Adhikari et al., 2021). Otherwise, if the game is not fun even though it can enhance specific language skills, it cannot be said to be a language game. A language game must meet two conditions, such as being fun and practicing language skills. If learning media is used by the characteristics of the material presented, it will make it easier for teachers to convey the material and help motivate students to learn. If students have been actively learning, it will facilitate the achievement of the expected learning objectives (Muna, 2014). Based on several theories described above, we can notice how students' learning outcomes at State Islamic Senior High School of 1 Malang Through The iqra' wheel game media can improve Arabic reading skills. 
Ta'lim al-'Arabiyyah : Jurnal Pendidikan Bahasa Arab dan Kebahasaaraban, 5 (2), 2021

\section{CONCLUSION}

Based on the research and analysis findings on the effectiveness of the iqra' wheel game to enhance Arabic reading skills, it can be illustrated by calculating using the NGain test formula or the effectiveness test that the results are $38.23 \%$. It means it has a moderate level of effectiveness. This can be evidenced by the average pre-test value of 84.41 while the post-test average is 90.58 . Moreover, from the results of $t$, the value of Sig (2-tailed) 0.001 was obtained. It means there is a difference in the pre-test and posttest scores in improving Arabic reading skills after the iqra' wheel game is applied. Hence, it can be expressed that the iqra' wheel game effectively enhances students' Arabic reading skills at State Islamic Senior High School of 1 Malang.

\section{REFERENCES}

Adhikari, R., Kydonaki, J., Lawrie. (2021). A Mixed-Methods Feasibility Study to Assess the Acceptability And Applicability Of Immersive Virtual Reality Sepsis Game As An Adjunct To Nursing Education. Nurse Education Today, 103(1), 1-11. https://doi.org/ 10.1016/j.nedt.2021.104944

Al-Basheer, A., Ashraah, M., Alsmadi, R. (2015). Arabic Language Teachers and Islamic Education Teachers' Awareness of Authentic Assessment In Jordan. Teacher Development, 19(4), 483-496. https://doi.org/10.1080/13664530.2015.1064824

Baroroh, R., Mardliyyah, A. (2019). Development of the Ladder Snake Game Media in Arabic Learning/ Pengembangan Media Permainan Ular Tangga Dalam Pembelajaran Bahasa Arab. Ijaz Arabi Journal of Arabic Learning, 2(1), 64-76. https://doi.org/10.18860/ijazarabi.v2i1.5445

Fahrurrozi, A. (2014). Pembelajaran Bahasa Arab Problematika Dan Solusinya. ARABIYAT Jurnal Pendidikan Babasa Arab dan Kebahasaaraban, 1(2), 162-179. https://doi.org/ 10.15408/a.v1i2.1137

Hamzah, Utami., S U, Zulkarnain. (2019). Pengembangan Media Pembelajaran Roda Putar Fisika untuk Meningkatkan Motivasi Belajar Siswa. Jurnal Hasil Kajian, Inovasi, dan Aplikasi Pendidikan Fisika, 5(2), 77-80. https://doi.org/10.31764/orbita.v5i2.1192

Hermawan, H. (2019). Riset Hospitalitas Metode Kuantitatif untuk Riset Bidang Kepariwisataan. Yogyakarta: Open Scince Framework.

Ignacio, J., Chen, H. (2020). The Use of Web-Based Classroom Gaming to Facilitate Cognitive Integration In Undergraduate Nursing Students: A Mixed Methods Study. Nurse Education in Practice, 46, 102820. https://doi.org/10.1016/j.nepr.2020.102820

Irdawati, Yunidar, dan Darmawan. (2017). Meningkatkan Kemampuan Membaca Permulaan Dengan Menggunakan Media Gambar Kelas 1 di Min Buol. urnal Kreatif Tadulako Online, 4(5), 1-14. http://jurnal.untad.ac.id/jurnal/index.php/JKTO/article/view/2918 
Lutfiyatun, E. (2015). Pengembangan Media Game Edukasi Berbasis Adobe Flash CS5 pada Keterampilan Menulis Bahasa Arab Untuk Siswa Kelas VIII MTs. Skripsi. Semarang: Universitas Negeri Surabaya. Tidak Diterbitkan.

Mancheva., L., Reichle, E., Lemaire, B. (2015). An Analysis of Reading Skill Development Using E-Z Reader. Journal of Cognitive Psychology, 27(5), 657-676. https://doi.org/10.1080/20445911.2015.1024255

Muna, W. (2014). Kartu Permainan: Media Pembelajaran Bahasa Arab Kontekstual. Jurnal Al-Ta'dib, 7(1), 4-100. https://doi.org/10.31332/atdb.v7i1.24모

Muradi, A., (2013). Tujuan Pembelajaran Bahasa Asing (Arab) Di Indonesia. AlMaqoyis, 2(1), 128-136. https://doi.org/ 10.30997/tipba.v1i2.3091

Murda, N., Purwanti, P. (2017). Penerapan Strategi Pembelajaran Think Pair Share untuk Meningkatkan Kemampuan Membaca Intensif Siswa. International Journal of Elementary Education, 1(1), 11-18. https://doi.org/10.23887/ijee.v1i1.11434

Priyatni, E. (2014). Pengembangan Bahan Ajar Membaca Kritis Berbasis Intervensi Responsif. Jurnal Litera, 13(1), 1-13. https://doi.org/10.21831/ltr.v13i1.1900

Sumantri, M., Sudana, D., Adnyana, I. (2017). Penerapan Media Gambar Dan Kartu Huruf Untuk Meningkatkan Keterampilan Membaca Permulaan. International Journal of Elementary Education, 1(1), 1-10. https://doi.org/ 10.23887/ijee.v1i1.11433

Verhoeven, L., Pefetti, C. (2011). Introduction To This Special Issue: Vocabulary Growth and Reading Skill. Scientific Studies of Reading, 15(1), 1-7. https://doi.org/ 10.1080/10888438.2011.536124

Whitton, N., Maclure, M. (2017). Video Game Discourses and Implications for GameBased Education. Discourse, 38(4), 561-572. https://doi.org/10.1080/01596306.2015.1123222

Zedan, A., Kadir, F., Yusof, M. (2013). The Role of Language in Education: Arabic as Case Study. Procedia - Social and Behavioral Sciences, 70, 1002-1008. https://doi.org/ 10.1016/j.sbspro.2013.01.151 